\title{
Penerapan Penyemprot Tanaman Elektrik untuk Lahan Pertanian di Desa Kuta Dame
}

\author{
Bakti Dwi Waluyo*, Ressy Dwitias Sari, Sapitri Januariyansah, Eka Dodi Suryanto \\ Fakultas Teknik, Universitas Negeri Medan \\ Email: bakti_dw@unimed.ac.id
}

\begin{abstract}
Kuta Dame Village is located in the Kerjaan District, Pakpak Bharat Regency, North Sumatra Province. Most of the people in Kuta Dame Village work as farmers. The primary agricultural commodities in Kuta Dame Village are rice, corn, and red chilies. Through the agriculture department, the local government has tried to increase agricultural output by providing counseling and training. However, the counseling did not touch on the effective and efficient technology aspects. One of the technologies that need to be applied in agricultural land is the electric crop spray system. An automatic spraying system is necessary because most farmers use the carrying type manual atomizer (diaphragm pump). The pump pressure's quality with the diaphragm system depends on the operator in moving the pump lever. This quality affects the quality of the spray grain to become uneven and uneven on the leaf surface. A community service program was carried out to implement an electric plant spray system because of these problems. Implementing activities starts from planning activities, counseling, the practice of using tools, monitoring, and evaluation. This activity resulted in ten out of fifteen participants stating that they were delighted because the automatic spraying system can save energy, time, fertilizers, and pesticides.
\end{abstract}

Keywords: Electric Sprayer System, Appropriate Technology, Kuta Dame Village

\begin{abstract}
Abstrak
Desa Kuta Dame terletak di Kecamatan Kerajaan, Kabupaten Pakpak Bharat Provinsi Sumatera Utara. Dimana sebagian besar masyarakat di Desa Kuta Dame berprofesi sebagai petani. Komoditas utama pertanian di Desa Kuta Dame adalah padi, jagung, dan cabai merah. Pemerintah daerah melalui dinas pertanian telah berusaha untuk meningkatkan hasil pertanian, salah satunya dengan memberikan penyuluhan dan pelatihan. Namun penyuluhan tersebut tidak menyentuh aspek teknologi tepat guna yang efektif dan efisien. Salah satu teknologi yang perlu diterapkan di lahan pertanian adalah sistem penyemprot tanaman elektrik. Sistem penyemprotan otomatis sangat dibutuhkan karena mayoritas petani menggunakan alat penyemprot manual (pompa diafragma) tipe gendong. Kualitas tekanan pompa dengan sistem diafragma bergantung terhadap operator dalam menggerakkan tuas pompanya. Hal ini berakibat terhadap kualitas butiran semprotan menjadi tidak halus dan tidak merata mengenai permukaan daun. Karena permasalah tersebut program pengabdian kepada masyarakat (PKM) dilakukan untuk menerapkan sistem penyemprot tanaman elektrik. Metode pelaksanaan kegiatan PKM dimulai dari perencanaan kegiatan, penyuluhan, praktek penggunaan alat, monitoring dan evaluasi. Hasil dari kegiatan PKM ini adalah sepuluh dari lima belas peserta menyatakan sangat puas, karena sistem penyemprot otomatis dapat menghemat tenaga, waktu, pupuk, dan pestisida.
\end{abstract}

Kata Kunci: Sistem Penyemprot Elektrik, Teknologi Tepat Guna, Desa Kuta Dame

\section{PENDAHULUAN}

Desa Kuta Dame berada di Kecamatan Kerajaan yang terletak di Kabupaten Pakpak Bharat. Desa Kuta Dame memiliki luas wilayah $18 \mathrm{Km}^{2}$, atau sekitar $12.17 \%$ rasio terhadap luas Kecamatan Kerajaan dengan jumlah penduduk 9.827 jiwa [1]. Kondisi wilayah Desa Kuta Dame pada 
umumnya berbukit-bukit dan berada di atas ketinggian 500 meter hingga 1.040 meter di atas permukaan laut. Sebagian besar penduduk di Desa Kuta Dame bermata pencaharian sebagai petani. Komoditas pertanian yang sering ditanam pada lahan pertanian adalah padi, jagung, kacang hijau, kacang tanah, dan cabai merah [2].

Dalam rangka meningkatkan potensi hasil komoditas pertanian, pemerintah daerah telah melakukan penyuluhan dan pelatihan. Tetapi, sebagian pelatihan yang dicoba masih kurang berfokus pada pengembangan teknologi tepat guna untuk menunjang pertanian. Dampaknya, petani masih kurang efisien dalam meningkatkan mata pencahariannya [3].

Berdasarkan survey awal ke Desa Kuta Dame, ditemukan bahwa selama ini petani masih menggunakan alat penyemprot manual tipe gendong dalam melakukan perawatan tanaman. Penyemprot manual dengan pompa manual (pompa diafragma) menggunakan tuas yang digerakkan turun naik dengan tangan kiri operator. Berdasarkan hasil kinerja menggunakan penyemprot manual ini, didapatkan bahwa intensitas dan jarak penyemprotan cairan secara masih sangat terbatas. Akibatnya intensitas cairan yang dikeluarkan tidak halus sehingga tidak sampai kepermukaan daun dengan merata [4]. Selain itu, dengan menggunakan sprayer manual ini, operator cepat kelelahan. Sehingga target luasan lahan yang diaplikasi dalam waktu yang disediakan tidak dapat dicapai [5].

Berdasarkan permasalah yang telah diuraikan, maka diperlukan tindakan untuk mengatasi kinerja dan sistem penyemprotannya. Untuk mendapatkan intensitas semprot yang lebih halus maka tekanan semprot perlu dinaikkan. Demikian juga kapasitas aplikasi luasan lahan penyemprotannya dapat ditingkatkan karena operator tidak lagi memompa secara manual sehingga tidak cepat lelah. Maka target luasan lahan yang diaplikasikan dapat dicapai sesuai waktu yang ditargetkan.

Berdasarkan permasalahan yang telah ditemukan diterapkan lah alat penyemprot elektrik untuk mendukung kegiatan pertanian di Desa Kuta Dame. Dengan penerapan teknologi tepat guna ini diharapkan mampu membantu kelompok tani dalam meningkatkan produktivitas hasil pertanian. Sehingga membawa dampak baik pada peningkatan kesejahteraan anggota kelompok tani.

Untuk mendukung hal tersebut, kelompok tani di Desa Kuta Dame menjalin kerjasama dengan Lembaga Penelitian dan Pengabdian pada Masyarakat (LPPM) Universitas Negeri Medan menyelenggarakan program kemitraan masyarakat (PKM) yang berfokus pada pengembangan teknologi tepat guna bagi masyarakat petani. Pada awalnya LPPM Unimed melakukan kajian terkait masih kurangnya pengembangan teknologi dalam aspek pertanian di Desa Kuta Dame. Hasil kajian tersebut menunjukkan adanya permasaahan, yaitu minimnya wawasan masyarakat dalam inovasi teknologi tepat guna. Oleh sebab itu, dirumuskan penyuluhan untuk mengembangkan teknologi tepat guna dalam bidang pertanian. Tujuan dari kegiatan program pengabdian ini adalah untuk meningkatkan pemahaman dan keterampilan masyarakat dalam penggunaan dan perawatan alat penyemprot elektrik dalam sektor pertanian.

\section{METODE PENGABDIAN}

Desa Kuta Dame berada di Kecamatan Metode yang digunakan dalam pelaksanaan kegiatan pengabdian masyarakat ini adalah Participatory Rural Appraisal (PRA). Metode PRA yaitu suatu metode pendekatan dalam proses pemberdayaan untuk meningkatkan partisipasi masyarakat yang penekanannya pada keterlibatan peserta dalam 
keseluruhan kegiatan yang dilaksanakan [6][7].

Adapun tahapan-tahapan kegiatan pengabdian kepada masyarakat yang dilakukan dapat dilihat pada Gambar 1.

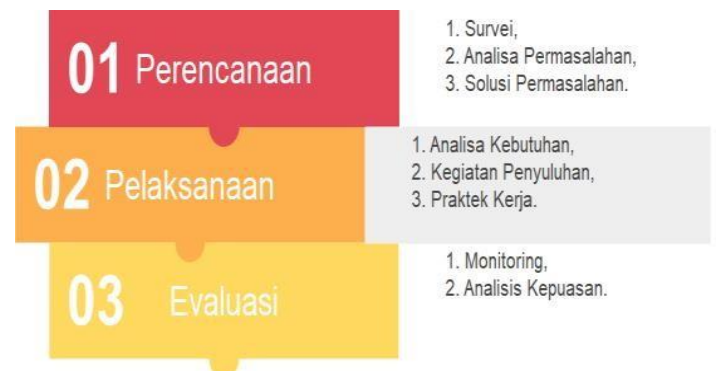

Gambar 1. Alur pelaksanaan kegiatan pengabdian kepada masyarakat.

Gambar 1 merupakan alur metode pelaksanaan kegiatan pengabdian masyarakat dengan penjelasan sebagai berikut:

\section{A. Perencanaan Kegiatan}

Pada tahap ini melakukan kunjungan lapangan (survei) untuk melakukan analisis situasi mengenai permasalahan dalam menerapkan teknologi tepat guna dalam sektor pertanian di Desa Kuta Dame. Selanjutnya melakukan analisa untuk menyelesaikan permasalahan yang ada sesuai dengan kebutuhan petani dengan cara melakukan koordinasi dengan masyarakat. Hasil koordinasi dijadikan acuan dalam penyusunan kegiatan pengabdian masyarakat.

\section{B. Pelaksanaan Kegiatan}

Dalam rangka mempersiapkan kegiatan pengabdian kepada masyarakat terkait penerapan alat penyemprot tanaman elektrik di lahan pertanian Desa Kuta Dame. Tim pengabdian terlebih dahulu menganalisa kebutuhan untuk mendukung kegiatan penyuluhan yang dilakukan. Selanjutnya tim pengabdian melakukan penyuluhan dengan diawali memberikan gambaran teori mengenai pemanfaatan teknologi tepat guna untuk sektor pertanian. Kemudian tim kegiatan pengabdian mempersiapkan alat dan bahan yang digunakan untuk melakukan pendampingan dalam menggunakan alat penyemprot elektrik.

\section{Evaluasi}

Pada tahap ini, dilakukan evaluasi proses penerapan alat penyemprot elektrik kepada anggota kelompok tani di Desa Kuta Dame. Kegiatan evaluasi ini bertujuan untuk melakukan monitoring terhadap kegiatan pengabdian masyarakat tentang penerapan teknologi tepat guna. Hasil dari monitoring dapat digunakan sebagai dasar acuan untuk menganalisa kendala dalam kegiatan pengabdian. Selain itu, kegiatan monitoring juga dapat digunakan untuk menganalisa tingkat kepuasan terhadap kegiatan pengabdian yang dilaksanakan.

\section{HASIL DAN PEMBAHASAN}

Kegiatan pengabdian kepada masyarakat dilaksanakan dikawasan pertanian milik masyarakat yang mengikuti kegiatan ini. Program pengabdian ini dilakukan dalam bentuk penyuluhan dan praktik penggunaan dan perawatan alat penyemprot elektrik untuk lahan pertanian di Desa Kuta Dame.

Hasil dari tahapan pelaksanaan kegiatan penyuluhan dan penerapan alat penyemprot elektrik di Desa Kuta Dame adalah sebagai berikut:

\section{A. Perencanaan Kegiatan}

Pada tahap perencanaan kegiatan, dilakukan survei awal terkait dengan teknologi pertanian yang saat ini digunakan oleh petani di Desa Kuta Dame (Gambar 2). Ditemukan bahwa teknologi yang digunakan oleh petani masih bersifat manual. Salah satu teknologi yang masih bersifat manual adalah alat penyemprot tanaman. Penggunaan alat penyemprot manual menyebabkan hasil semprotan 
tidak merata. Selain itu, teknologi ini menyebabkan kelelahan bagi para penggunanya. Oleh karena itu, diperlukan inovasi alat penyemprot elektrik yang mampu mengatasi permasalahan petani di Desa Kuta Dame.

Berdasarkan analisa permasalahan tersebut, LPPM beserta kelompok tani desa kuta dame melakukan koordinasi untuk menyelenggarakan kegiatan pengabdian kepada masyarakat terkait dengan penerapan alat penyemprot elektrik. Kegiatan pengabdian kepada masyarakat ini diselenggarakan dengan melibatkan beberapa mahasiswa dalam proses pelaksanaan.

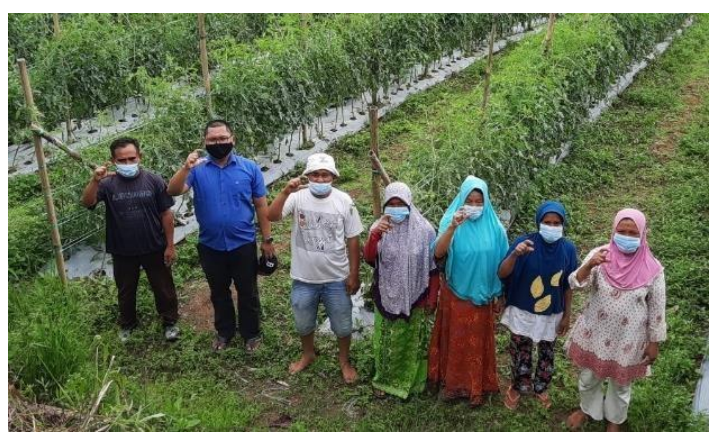

Gambar 2. Survei awal ke lahan pertanian di Desa Kuta Dame

\section{B. Pelaksanaan Kegiatan}

Tim pelaksana PKM mempersiapkan bahan maupun materi yang digunakan untuk penerapan alat penyemprot elektrik. Jenis peralatan yang disediakan untuk kegiatan pengabdian ini adalah pompa air, penyemprot elektrik, dan peralatan perawatan perbaikan. Peralatan-peralatan yang dapat dilihat pada Gambar 3.

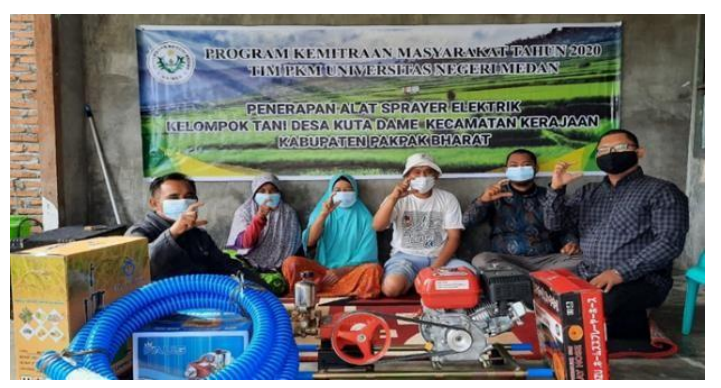

Gambar 3. Pelaksanaan kegiatan pengabdian kepada masyarakat

Pada tahap awal, para petani memperoleh materi terkait dengan penerapan teknologi tepat guna untuk pertanian. Penyampaian materi ini dilakukan oleh Bakti Dwi Waluyo. Tahapan berikutnya, anggota kelompok tani mendapat penyuluhan terkait dengan penggunaan dan perawatan alat penyemprot elektrik yang disampaikan oleh Eka Dodi Suryanto. Setelah seluruh materi dijelaskan, tahapan pelaksanaan berikutnya adalah praktek penggunaan dan perawatan alat penyemprot elektrik. Pada tahap ini, mahasiswa dilibatkan untuk melakukan pendampingan dalam penggunaan dan perawatan alat penyemprot elektrik.

Selanjutnya tim PKM memberikan petunjuk pengoperasian dan perawatan mesin pompa air dan penyemprot elektrik. Materi penyuluhan pengoperasian dan perawatan mesin pompa air adalah:

1. Prinsip kerja penggerak mesin pompa

2. Prinsip kerja pompa air

3. Komponen-komponen utama pada mesin penggerak dan pompa air

4. Prosedur pengoperasian mesin pompa air

5. Prosedur perawatan mesin pompa air.

C. Pengujian Penyemprot Elektrik Penyemprot elektrik diterapkan dalam aplikasi pupuk daun di beberapa petak lahan pertanian. Pola penerapan terhadap lahan pertanian dapat dilihat pada Gambar 4. Dimana terlebih dahulu tangki air diisi dengan pupuk daun, kemudian mikrokontroler dan pompa air dinyalakan. Untuk memulai dan mengakhiri penyemprotan dilakukan secara manual oleh operator dengan menekan tombol start dan stop.

Berdasarkan hasil pengamatan dalam aplikasi pupuk daun menggunakan 
penyemprot elektrik kualitas semprotannya bertambah baik. Butiran semprotan halus cenderung seperti kabut, sehingga semua daun terkena semprotan secara merata.

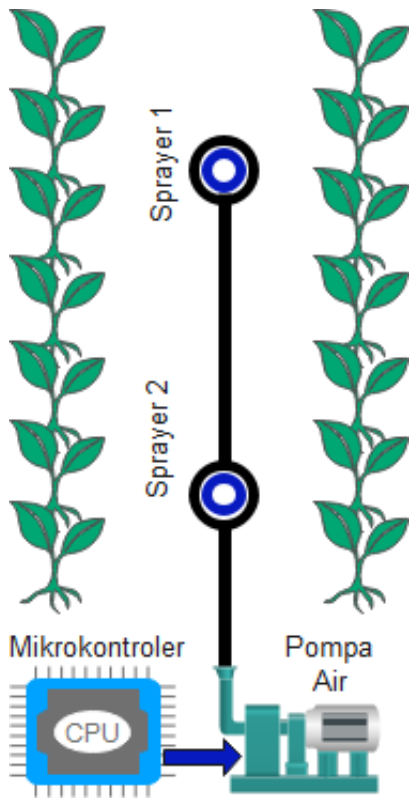

Gambar 4. Pola penyemprotan

D. Evaluasi

Tim pelaksana kegiatan pengabdian masyarakat melakukan evaluasi terhadap kegiatan penerapan alat penyemprot elektrik. Evaluasi ini bertujuan untuk mengetahui tingkat kepuasan anggota kelompok tani di Desa Kuta Dame dalam mengikuti kegiatan dari awal sampai akhir. Berdasarkan evaluasi terhadap 15 orang anggota kelompok tani, mayoritas peserta sangat puas dengan kegiatan pengabdian ini. Grafik tingkat kepuasan peserta terhadap kegiatan penyuluhan alat penyemprot otomatis dapat dilihat pada Gambar 5.

Berdasarkan Gambar 1, 10 orang dari 15 anggota kelompok tani yang mengikuti penyuluhan menyatakan sangat puas. Sementara 4 orang menyatakan puas dan 1 orang menyatakan tidak puas. Dari hasil ini dapat disimpulkan bahwa anggota kelompok tani desa kuta dame puas dengan kegiatan yang telah dilaksanakan. Namun begitu, proses monitoring dan pendampingan masih sangat perlu dilakukan. Tujuannya adalah untuk mengamati perkembangan alat penyemprot elektrik dalam mendukung pertanian di Desa Kuta Dame.

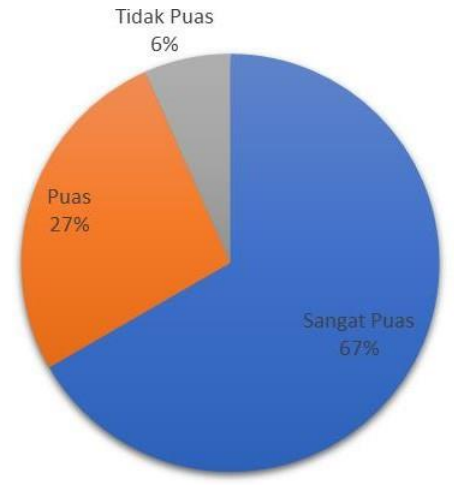

Gambar 5. Grafik tingkat kepuasan peserta penyuluhan alat penyemprot elektrik

\section{SIMPULAN}

Dengan adanya kegiatam program kemitraan masyarakat tahun 2020 dapat menyelesaikan permasalahan pada kelompok tani di Desa Kuta Dame. Secara umum, PKM dengan tema penerapan alat penyemprot elektrik ini memiliki hasil sebagai berikut:

1. Teknologi tepat guna berupa alat penyemprot elektrik yang digunakan untuk mendukung sektor pertanian di desa kuta dame.

2. Peningkatan tingkat pemahaman anggota kelompok tani di Desa Kuta Dame terhadap pentingnya inovasi teknologi tepat guna.

Dalam rangka meningkatkan inovasi teknologi tepat guna, masyarakat diharapkan dapat mengembangkan teknologi alat penyemprot elektrik menggunakan tenaga surya sebagai sumber listrik. 


\section{UCAPAN TERIMAKASIH}

Penulis mengucapkan terimakasih kepada pihak yang telah berkontribusi / mendukung penelitian ini yaitu Lembaga Penelitian dan Pengabdian Masyarakat (LPPM) Universitas Negeri Medan. Dimana penelitian ini didanai oleh DIPA Unimed tahun anggaran 2020.

\section{DAFTAR PUSTAKA}

[1] B. P. S. K. P. Bharat, "Kecamatan Kerajaan Dalam Angka," Pakpak Bharat, 2020.

[2] B. P. Statistik, "Statistik Daerah Kabupaten Pakpak Bharat 2020," Pakpak Bharat, 2020.

[3] E. Ronando and E. Indasyah, "Penyuluhan Alat Sprayer Elektrik Bagi Masyarakat Petani Desa Wonodadi Wetan Kabupaten Pacitan," Jurnal ABDI, vol. 3, no. 2, p. 63, 2018, doi: 10.26740/ja.v3n2.p63-67.

[4] W. Hermawan, "Kinerja Sprayer Bermotor Dalam Aplikasi Pupuk Daun Di Perkebunan Tebu," Jurnal Keteknikan Pertanian, vol. 26, no. 2, p. 21831, 2012.

[5] M. Rahman and M. Yamin, "Modifikasi Nosel pada Sistem Penyemprotan untuk Pengendalian Gulma Menggunakan Sprayer Gendong Elektrik," Jurnal Keteknikan Pertanian, vol. 2, no. 1, p. 21957 , 2014.

[6] B. Baihaqi, Imam Hadi Sutrisno, and Zidni Ilman Navia, "Budidaya Ikan Lele (Clarias SP) Dengan Sistim Kolam Bioflok Pada Pokdakan Tanah Berongga-Sido Urep," Jurnal Pengabdian UntukMu NegeRI, vol. 4, no. 2, pp. 160-164, 2020, doi: 10.37859/jpumri.v4i2.2033.

[7] B. Baihaqi, Abdul Latief, Agus Putra AS, and Adi Bejo Suwardi, "Pemberdayaan Pokdakan Tanah Berongga-Sido Urep Melalui Budidaya Lele Bioflok Autotrof di Kabupaten Aceh Tamiang," Jurnal
Pengabdian UntukMu NegeRI, vol. 4, no. 2, pp. 180-186, 2020, doi: 10.37859/jpumri.v4i2.2103. 